
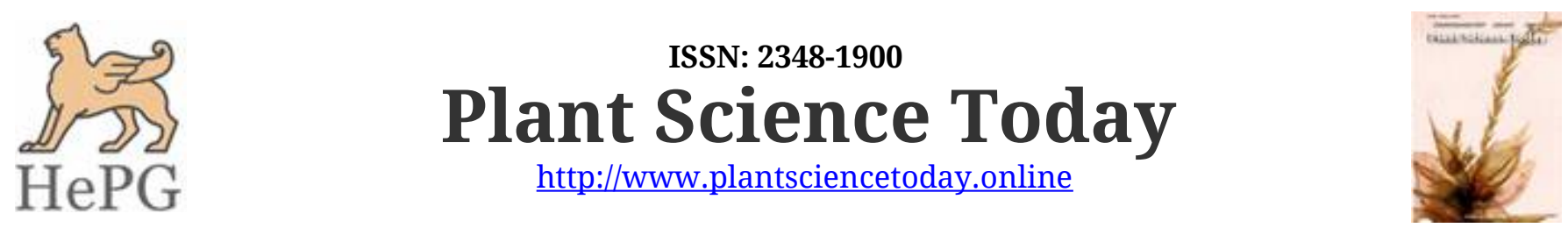

OPEN 2 ACCESS

Research Article

\title{
Arsenic stress on photosynthesis and growth in Ipomoea aquatica
}

\author{
Jagadish Chandra Joardar, Nishad Afrin \& Milton Halder*\$ \\ Soil, Water and Environment Discipline, Khulna University, Khulna-9208, Bangladesh \\ ${ }^{\$}$ Current address: Institute of Soil Science, Chinese Academy of Sciences, Nanjing 210008, P. R. China
}

\section{Article history}

Received: 13 June 2019

Accepted: 25 July 2019

Published: 01 October 2019

\section{Publisher}

Horizon e-Publishing Group

\section{*Correspondence}

Milton Halder

$\square_{\text {soilmilton06@gmail.com }}$

\begin{abstract}
An experiment was conducted to understand the effect of arsenic (As) on photosynthetic pigments in Ipomoea aquatica leaves, its growth performance and As uptake in edible plant parts. The experiment was designed with three levels of As treatments, viz. 10, 20, and $40 \mathrm{mg} \mathrm{As} \mathrm{kg}^{-1}$ soil along with control, and three biological replications. I. aquatica was grown for six weeks after seed germination. Chlorophyll-a, chlorophyll-b, carotenoid, plant height and weight increased at lower rate of As application $\left(10 \mathrm{mg} \mathrm{kg}^{-1}\right)$ in soil.

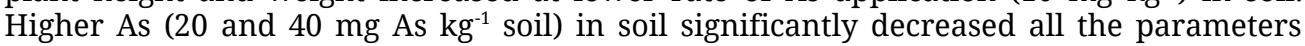
except carotenoid. Both plant height and weight were significantly reduced at $20 \mathrm{mg}$ As $\mathrm{kg}^{-1}$ in soil. Chlorophyll-a and chlorophyll-b content were significantly reduced at $40 \mathrm{mg}$ As $\mathrm{kg}^{-1}$ in soil. Arsenic concentration in plant parts increased significantly at higher As concentration and exceeded the maximum limit of As $\left(0.5 \mathrm{mg} \mathrm{kg}^{-1}\right)$ for vegetables at $20 \mathrm{mg}$ As $\mathrm{kg}^{-1}$ soil and above. Arsenic uptake $\left(\mu \mathrm{g}\right.$ plant $\left.{ }^{-1}\right)$ also increased significantly with elevated levels of soil As (40 mg kg-1). Considering the growth performance, I. aquatica should not be recommended to grow where the soil As concentration is $20 \mathrm{mg} \mathrm{kg}^{-1}$ and above.
\end{abstract}

Keywords: Soil arsenic; Ipomoea aquatica; photosynthetic pigments; growth.

Citation: Joardar J C, Afrin N, Halder M. Arsenic stress on photosynthesis and growth in Ipomoea aquatica. Plant Science Today 2019; 6(4):420-426. https://doi.org/10.14719/pst.2019.6.4.589

Copyright: ( ) Joardar et al (2019). This is an open-access article distributed under the terms of the Creative Commons Attribution License, which permits unrestricted use, distribution, and reproduction in any medium, provided the original author and source are credited (https://creativecommons.org/licenses/by/4.0/).

Indexing: Plant Science Today is covered by Scopus, Web of Science, BIOSIS Previews, ESCI, CAS, AGRIS, CABI, Google Scholar, etc. Full list at http://www.plantsciencetoday.online

\section{Introduction}

Arsenic is one of the toxic environmental pollutants because of its chronic and epidemic effects on human health through widespread drinking water and taking vegetables/crops grown on As contaminated growth medium. Naturally, As is present in soil all over the world depending on the origin of the soil (1). The background concentration of soil As is approximately $5 \mathrm{mg} \mathrm{kg}^{-1}$ (2). Generally, non-contaminated soils contain As ranging 0.1-10 $\mathrm{mg} \mathrm{kg}{ }^{-1}$ (3). Bangladesh soil As concentration is higher than this value and it varies location to location. The average soil As concentration in Bangladesh is $12.3 \mathrm{mg} \mathrm{kg}^{-1}$. Different studies documented different As concentration in Bangladesh soil ranges from 0.3 to $56.7 \mathrm{mg} \mathrm{kg}^{-1}$ (47). Most of the population of the country mainly 
depends on groundwater for irrigation during the dry season cultivation. Bangladesh groundwater is naturally contaminated with As ranging from $<1$ to $1,500 \mu \mathrm{g} \mathrm{L}^{-1}$ (8). About $46 \%$ of the groundwater in Bangladesh exceeds the World Health Organization (WHO) guideline for drinking water As $\left(0.01 \mathrm{mg} \mathrm{L}^{-1}\right)$ and $27 \%$ exceeds the Bangladesh drinking water (0.05 $\left.\mathrm{mg} \mathrm{L}^{-1}\right)$ guideline (8). Irrigating with As contaminated water caused a substantial accumulation of As in the soil (9-10).

The most important biochemical event on earth is photosynthesis which converts sunlight into electrical and then chemical energy (11). The most important photosynthetic pigment is chloroplast (chlorophyll-a and chlorophyll-b). They differ from each other and absorb light of different wavelength to perform photosynthesis. Leaf pigment content provides valuable information about the physiological status of plants and can indicate the metal intoxication (12). Furthermore, leaf chlorophyll content is closely related to plant stress and senescence (13). Carotenoids play the structural role in the organization of photosynthetic membranes, participation in light harvesting, energy transfer, interception of deleterious free oxygen and organic radicals and quenching (14). Carotenoids also protect the plant from free radicals formed through ultra violet or other radiation.

Arsenic at higher concentration is toxic to most plants (15). It interferes with metabolic processes and inhibits plant growth and development through As induced phytotoxicity (16). When plants are exposed to excess As either
Bangladesh with or without irrigation facilities throughout the year. The main benefit is that when seeds are shown once in a year, yield can be obtained throughout the year as it has regrowth capacity from its shoot. The present study was undertaken to evaluate the effects of soil As on photosynthetic pigments in leaves of I. aquatica as well as its growth performance and As uptake in edible plant parts.

\section{Materials and Methods}

\section{Soil sampling site}

The soil sample was collected from the agricultural field behind the Khulna University campus, Bangladesh, by following the composite soil sampling method as suggested by the United States Department of Agriculture (22). The geographic location of the sampling site was $22^{\circ} 48.302^{\prime} \mathrm{N}$ and $89^{\circ} 31.962 '$ E.

\section{Soil sample collection and preparation}

The bulk soil representing $0-15 \mathrm{~cm}$ depth from the surface was collected by using traditional spade. The collected soil belongs to the Pirojpur soil series; general soil type-dark grey non-calcareous tidal floodplain soil and USDA soil taxonomy-Typic Endoaquepts. After collection, the bulk soil was airdried and removed the grasses and other visible debris. Then the larger and massive aggregates were broken by gentle crushing with a wooden hammer and sieved through a $2.0-\mathrm{mm}$ sieve. The sieved soil was then mixed thoroughly to make the composite soil sample which was used for the

Table 1. Effect of soil As on different attributes of Ipomoea aquatica

\begin{tabular}{|c|c|c|c|c|c|c|}
\hline Soil As & Chl-a & Chl-b & Total Chl & Carotenoids & Plant height & Biomass \\
\hline$\left(\mathrm{mg} \mathrm{kg}^{-1}\right)$ & \multicolumn{4}{|c|}{$\left(\mu \mathrm{g} \mathrm{ml}^{-1}\right)$} & $(\mathrm{cm})$ & (g) \\
\hline Control & $16.25^{\mathrm{b}}( \pm 3.34)$ & $4.17^{\mathrm{ab}}( \pm 1.03)$ & $20.42^{\mathrm{b}}( \pm 4.23)$ & $3.53^{\mathrm{a}}( \pm 0.58)$ & $16.33^{\mathrm{a}}( \pm 1.53)$ & $0.87^{\mathrm{a}}( \pm 0.04)$ \\
\hline 10 & $20.06^{\mathrm{a}}( \pm 0.96)$ & $5.07^{\mathrm{a}}( \pm 0.31)$ & $25.14^{\mathrm{a}}( \pm 1.24)$ & $4.03^{\mathrm{a}}( \pm 0.27)$ & $18.67^{\mathrm{a}}( \pm 2.08)$ & $0.80^{\mathrm{a}}( \pm 0.05)$ \\
\hline 20 & $14.98^{\mathrm{b}}( \pm 1.40)$ & $4.44^{\mathrm{a}}( \pm 0.83)$ & $19.41^{\mathrm{b}}( \pm 2.0)$ & $3.92^{\mathrm{a}}( \pm 0.62)$ & $12.67^{\mathrm{b}}( \pm 1.53)$ & $0.61^{\mathrm{b}}( \pm 0.08)$ \\
\hline 40 & $9.40^{c}( \pm 1.43)$ & $2.95^{\mathrm{b}}( \pm 1.47)$ & $12.35^{\mathrm{c}}( \pm 2.41)$ & $2.92^{\mathrm{a}}( \pm 0.83)$ & $8.33^{\mathrm{c}}( \pm 1.53)$ & $0.45^{\mathrm{c}}( \pm 0.06)$ \\
\hline
\end{tabular}

* Chl = chlorophyll; Values are the average of replications $(\mathrm{n}=3)$; Different letters above the values indicate the significant differences $(p=0.05)$. Values within the parentheses are the standard deviations $(n=3)$

in soil or in solution culture, they exhibits inhibition of seed germination (17); decrease in plant height (18); depress in tillering (19); reduction in root growth (17); decrease in shoot growth (20); lower fruit and grain yield (18); and sometimes leads to death (21). Arsenic enters into food chain through plant uptake grown in As contaminated soil and/or irrigating with As contaminated water affects the food safety. Phytotoxicity of As to vegetable plants has been widely concerned because of large scale use of As contaminated groundwater for irrigation in Bangladesh crop field during the dry season. Little is known about the effect of As on photosynthetic pigments, the basis of plant bio-chemical system.

I. aquatica is a high yielding and very popular leafy vegetable. It is cultivated everywhere in experiment as the growth medium. A small portion of the soil sample from the composite soil was further sieved through a $0.5-\mathrm{mm}$ sieve and preserved for further laboratory analyses.

\section{Experiment set-up}

Twelve plastic pots of equal size (2-L) were used for plant growth. Two $\mathrm{kg}$ of processed soil was poured in each pot. There were four levels of As treatments (control, 10, 20 and $40 \mathrm{mg} \mathrm{As} \mathrm{kg}{ }^{-1}$ soil) with three replications (three pots for each treatment). Control also contained some As (6.9 mg $\mathrm{kg}^{-1}$ soil) because this amount of As is soil's background As. Soil As concentration was artificially varied by using sodium meta arsenite $\left(\mathrm{NaAsO}_{2}\right)$. The soil was well fertilized following the fertilizer recommendation guide (23) in Bangladesh. The pots were arranged completely 
randomized way and the positions were changed in alternative day to get the equal sun light. According to the treatment, the required amount of As-salt was mixed into the soil as solution and kept undisturbed for one week. Then, the soil was mixed again thoroughly and poured into the respective pots. When the soil was moist enough to germinate seed, then about 8-10 seeds of $I$. aquatica, which was collected from local market, were sown in each pot. After ten days from seed germination, the plants were thinned keeping 4-5 healthy plants in each pot. One week later, the plants were thinned again keeping only 3 strong and healthy plants in each pot and were allowed to grow for one more month. During the whole growth period, all visible symptoms were carefully observed and recorded. Six weeks after seed germination, the plants were harvested by cutting the stems of the plants at $1.0-\mathrm{cm}$ above the soil ground. Harvested stems together with the leaves were considered to be the edible parts of the plant. The harvested plant parts were washed well with distilled water to remove adhering soil particles on the plant surface. The collected plant samples were air-dried and the fresh weight of the plant samples were measured and recorded. A part of fresh plant samples were then processed for chlorophyll pigment analysis.

\section{Laboratory analyses}

Chlorophyll contents in I. aquatica leaves were determined spectrophotometrically. Fresh leaves were cut into small pieces and $100 \mathrm{mg}$ of the leaf was taken into a mortar to grind them finely by pestle with $5 \mathrm{ml}$ of $80 \%$ acetone. The extract was centrifuged for 20 minutes. The supernatant was transferred to a measuring cylinder and the process was repeated thrice to ensure that the supernatant was fully extracted and then the final volume was made up to $15 \mathrm{ml}$ by adding required volume of $80 \%$ acetone. The optical density of each solution was measured at 663 and $645 \mathrm{~nm}$ against $80 \%$ acetone blank following the method of Arnon (24). The amount of chlorophyll-a, chlorophyll-b, total chlorophyll and carotenoids were calculated according to the Lichtenthaler and Wellburn (25) formulae. Plant height and biomass were estimated as the indicator of growth performance. Plant height was recorded at the day of harvesting using measuring scale whereas the biomass (stem plus leaf) was measured after air dried.

The soil sample was digested with concentrated $\mathrm{HNO}_{3}$ and $\mathrm{HCl}$ (1:3) for the determination of total As and other elements. Whereas total As in plant was measured by digesting the plant samples with a mixture of $\mathrm{HNO}_{3}$ and $\mathrm{HClO}_{4}$. The concentration of As in the digest was determined by using atomic absorption spectrophotometer by following the prescribed laboratory methods (26). Reagent blanks were used to ensure the accuracy and precision in the analysis. The particle size analysis of the soil was done by combination of sieving and hydrometer method as described by Gee and Bauder (27). Textural classes were determined using Marshall's Triangular Coordinates as devised by United States Department of Agricultural (22). Soil pH (soil: water, 1:2.5) was determined electrochemically with the help of glass electrode $\mathrm{pH}$ meter as suggested by Jackson (28). The electrical conductivity of the soil was measured at a soil: water ratio of 1:5 with the help of EC meter (29). Total nitrogen of the soil was determined by Micro-Kjeldahl method following $\mathrm{H}_{2} \mathrm{SO}_{4}$ acid digestion (28). Available phosphorus was extracted from the soil with $0.5 \mathrm{M} \mathrm{NaHCO}_{3}$ at pH 8.5 (28) and $\mathrm{P}$ was determined by ascorbic acid blue color method (30). Available potassium was extracted by using neutral $1 \mathrm{~N} \mathrm{NH}_{4} \mathrm{OAC}$ (31) and the $\mathrm{K}$ content was determined using flame photometer. Total iron content was determined by spectrophotometer at $510 \mathrm{~nm}$ (32).

\section{Statistical analysis}

The results were expressed as the average of three replications. The data was subjected to ANOVA using computer built-in statistical software program Minitab-16. Differences between means were statistically analyzed using Fisher method $(p=0.05)$. Graphs were prepared by using computer built-in Microsoft Excel-2010 program.

\section{Results and Discussion}

Some important physical and chemical properties of initial soil, alternatively in control soil, used for plant growth are: texture-silty clay loam; $\mathrm{pH}-7.24$; EC-1.29 dS m ${ }^{-1}$; total $\mathrm{N}-0.18 \%$; available P-5.59 $\mu \mathrm{g}$ $\mathrm{g}^{-1}$; available $\mathrm{K}-0.23 \mu \mathrm{g} \mathrm{g}^{-1}$; total Fe-40.82 $\mu \mathrm{g} \mathrm{g}^{-1}$ and total As-6.9 mg kg-1.

\section{Chlorophyll content}

The chlorophyll contents of fresh leaves of $I$. aquatica plants are shown in Table 1. Chlorophylla content in the plant leaves increased significantly (Table 1) with compared to the control at lower As treatment (10 $\left.\mathrm{mg} \mathrm{kg}^{-1}\right)$, then it was decreased with increasing As concentration in the growth medium and significantly reduced at $40 \mathrm{mg} \mathrm{kg}^{-1}$ As in soil. The reduction of chlorophyll-a content was about $42 \%$ from the control plants at $40 \mathrm{mg} \mathrm{kg}^{-1}$ As in the soil (Table 1). Chlorophyll-b content also increased significantly with compared to the control up to $20 \mathrm{mg} \mathrm{kg}^{-1} \mathrm{As}$ in soil but it was significantly reduced at $40 \mathrm{mg} \mathrm{kg}^{-1}$ As in soil (Table 1). The reduction of chlorophyll-b content was about $30 \%$ from the control plants (Table 1). The significant reduction of both chlorophyll-a and chlorophyll-b was found in plants treated with 40 $\mathrm{mg} \mathrm{kg}^{-1}$ As in the growth medium. There was no significant difference in the content of carotenoids in plant leaves treated with different As concentrations (Table 1). But the trend was similar to that was observed in case of chlorophyll-a and chlorophyll-b. The reduction of carotenoids in plant parts was about $17 \%$ at $40 \mathrm{mg} \mathrm{kg}^{-1}$ As in soil 
as compared to the control plants. Total chlorophyll content (chlorophyll-a plus chlorophyll-b) was also followed the similar trend of chlorophyll-a (Table 1). It was significantly increased at $10 \mathrm{mg} \mathrm{kg}^{-1}$ then it was decreased and finally significantly decreased at $40 \mathrm{mg} \mathrm{kg}^{-1} \mathrm{As}$ in soil. The reduction was about $40 \%$ at $40 \mathrm{mg} \mathrm{kg}^{-1} \mathrm{As}$ in soil as compared to the control plants.

\section{Plant height}

Plant height on different levels of As treated soil is presented in Table 1. It was found that plant height was increased when plants were treated with lower rate of As $\left(10 \mathrm{mg} \mathrm{kg}^{-1}\right)$ but it was not statistically significant. Actually, plant height was significantly reduced with increasing rate of As (20 and $40 \mathrm{mg} \mathrm{kg}^{-1}$ ) in soil (Table 1).

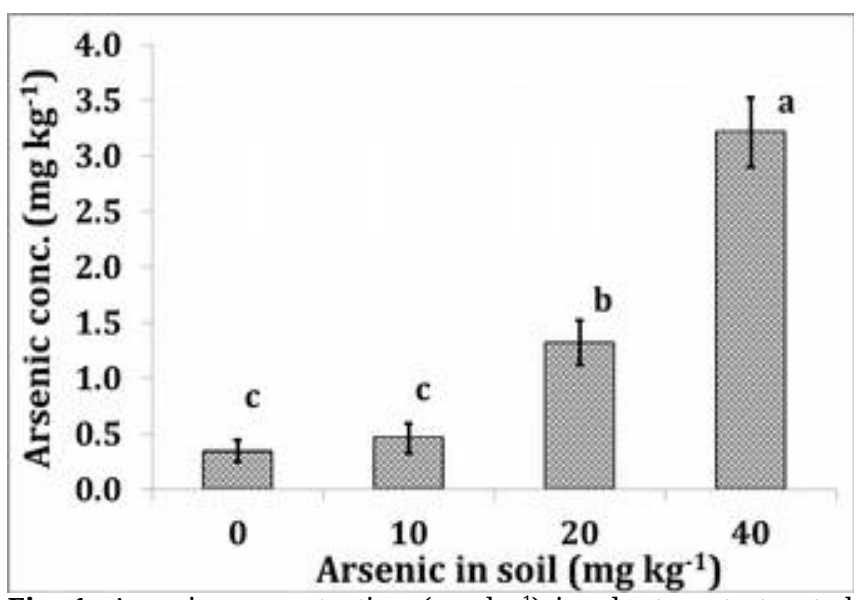

Fig. 1. Arsenic concentration (mg kg-1) in plant parts treated with different level of As in growth medium. Different letters above the bars indicate the significant differences $(p=0.05)$. Error bars are the standard deviations $(n=3)$.

\section{Biomass}

Biomass (stem plus leaf) production was reduced gradually with the increase of soil As (Table 1). Biomass reduction was significant at higher rate of As treatment $(20$ and $40 \mathrm{mg} \mathrm{kg}$ ). A significant negative correlation $(\mathrm{r}=-0.962 ; \mathrm{p}=0.038)$ between As in soil and total biomass was observed.

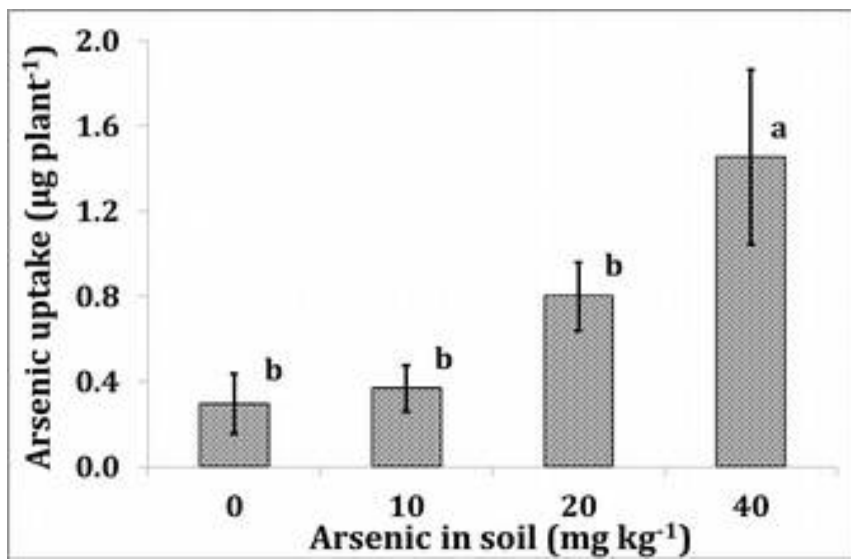

Fig. 2. Arsenic uptake ( $\mu \mathrm{g}$ plant $\left.^{-1}\right)$ in plant parts treated with different level of As in growth medium. Different letters above the bars indicate the significant differences $(p=0.05)$. Error bars are the standard deviations $(n=3)$.

\section{Arsenic in plant}

The mean values $(n=3)$ of the As concentration $(m g$ $\left.\mathrm{kg}^{-1} \mathrm{dw}\right)$ and As uptake $\left(\mu \mathrm{g}\right.$ plant $\left.{ }^{-1}\right)$ in plant parts are presented in Fig. 1 \& 2, respectively.

Arsenic concentration and As uptake was calculated by dry weight (dw) basis. Arsenic concentration in the edible plant parts was significantly higher in soil with higher As concentration (20 and $40 \mathrm{mg} \mathrm{kg}^{-1}$ ), but there were no significant differences in the soil with lower As concentration (10 $\mathrm{mg} \mathrm{kg}^{-1}$ ) (Fig. 1). Similar to the As concentration, As uptake in plant parts was significantly increased when grown in soil with elevated levels of As (40 mg kg-1) (Fig. 2).

The results revealed that the photosynthetic pigments reduced significantly with higher rate of As application (40 mg As kg-1) in soil. It was reported (33) that $25 \mathrm{mg} \mathrm{As} \mathrm{kg}^{-1}$ soil did not show any negative effect on the photosynthetic process in bean plants while the higher doses (50 and $100 \mathrm{mg} \mathrm{As} \mathrm{kg}^{-1}$ ) inhibited photosynthesis by 42 and $32 \%$ respectively. The present research revealed almost similar findings in $I$. aquatica leaves. There is no significant effect on the photosynthetic pigments of fresh $I$. aquatica leaves grown on soil containing up to $20 \mathrm{mg} \mathrm{As} \mathrm{kg}{ }^{-1}$ but significantly reduced at $40 \mathrm{mg}$ As $\mathrm{kg}^{-1}$. The insignificant growth of the plants was increased with lower rate of As application but the overall growth was significantly decreased with higher rate of As application (Table 1). At low soil As concentration, displacement of soil phosphate by arsenate increased the availability of phosphate to the plant, which might result in the increase of plant growth (34). The growth of plants increased at lower doses of As (35-36) under both soil and hydroponic culture. At higher soil As concentration, uptake of nutrient element inhibit in roots therefore the growth of the whole plant hampered and the plant biomass decreased (37). Decreased growth of the plants grown in Ascontaining medium was also reported $(35,38)$. Another reason of the reduction of growth in I. aquatica might be due to the reduced chlorophyll content in I. aquatica leaves due to As toxicity. It was reported that As inhibited the growth together with biomass production (39) and caused physiological disorders (40) as well as reduction in photosynthetic rate (33) and crop productivity (41). Chlorophyll content is of particular significance in agriculture as an indicator of photosynthetic activity. In the present study, chlorophyll contents reduced with higher rate of As application. It was also reported that high As concentration depressed chlorophyll content (42-43). The decrease in photosynthetic pigments under As treatments might be due to their toxic effect and it is the sign of absence of adaptive adjustments of pigment synthesis to high As levels. Another reason might be due to the fact that the increased soil As concentrations resulted in an alteration of the chloroplast shape with concaving membrane 
bending and partial destruction along with the changes in the accumulation and flow of assimilates leading to the decrease of chlorophyll contents (33).

Arsenic concentration in the edible plant parts exceeded the maximum limit of As $(0.5 \mathrm{mg}$ $\mathrm{kg}^{-1}$ ) for vegetables (44) when the plants were treated with $20 \mathrm{mg} \mathrm{kg}^{-1}$ As in soil and above (Fig. 1). It can be noted that there is no universal limit value of As in vegetables but only China had the maximum limit value of As for vegetables $(0.5 \mathrm{mg}$ $\mathrm{kg}^{-1}$ ), though some other countries (Australia, New Zealand, Singapore and UK) have the maximum limit value of As for cereals. The maximum limit value in rice in those countries is $1.0 \mathrm{mg} \mathrm{kg}^{-1}$ and that of India is $1.1 \mathrm{mg} \mathrm{kg}^{-1}$ (44). The CODEX committee on contaminants in foods proposed maximum level (ML) for inorganic As in polished rice is $0.2 \mathrm{mg} \mathrm{kg}^{-1}$ (45). In this experiment, the soil contained As of $6.9 \mathrm{mg} \mathrm{kg}^{-1}$ so As concentration of the control plants was very low. Both organic and inorganic forms of As are present in terrestrial plants (46) but As in terrestrial food plants is dominated by inorganic As (47) and in case of peas and spinach only inorganic As was present. In the present experiment, organic and inorganic As could not be separately measured, only the total As content was measured. It is reported that in the Bengal Delta region, most of the As in vegetables and spices are inorganic forms (48-49). The As concentration in the edible parts was about three and seven times higher than the maximum limit for vegetables of $0.5 \mathrm{mg} \mathrm{kg}^{-1}$ when grown at 20 and $40 \mathrm{mg} \mathrm{As} \mathrm{kg}^{-1}$ soil, respectively (Fig. 1). In contrast, As concentration in plants grown at $10 \mathrm{mg} \mathrm{As} \mathrm{kg}^{-1}$ were very close $\left(0.46 \mathrm{mg} \mathrm{As} \mathrm{kg}^{-1}\right)$ to the maximum limit. Arsenic concentration in non-contaminated soils ranges from 0.1 to $10 \mathrm{mg} \mathrm{kg}{ }^{-1}$ (3). In the experiment, soil As concentration $\left(6.9 \mathrm{mg} \mathrm{kg}^{-1}\right)$ was within the range of non-contaminated soil and As concentration in the plants was very low as compared with the maximum limit. Therefore, it was considered that the As concentration in soil having $20 \mathrm{mg} \mathrm{kg}^{-1}$ increased the As concentration in plants. It seemed clear that if the soil contained As up to $20 \mathrm{mg} \mathrm{kg}^{-1}$, the vegetable grown in it would exceed the maximal limit.

\section{Conclusion}

Considering the photosynthetic pigments in plant leaves, biomass production of the plants and the more concerning matter the As concentration and As uptake in edible plant parts regarding food security, I. aquatica should not be grown in soil where the soil As concentration is $20 \mathrm{mg} \mathrm{kg}^{-1}$ and above. So, $20 \mathrm{mg} \mathrm{As} \mathrm{kg}{ }^{-1}$ in soil might be the risk value for the plant $I$. aquatica. This risk value may differ depending on the climate, soil types and species of vegetables. More research needs to be conducted using many types of vegetables for the safety of food production. The risk of higher concentrations of As in soil in the vegetable cultivation was clearly shown.

\section{Competing Interests}

The authors declare that they have no competing interests.

\section{Author's contribution}

JCJ designed and supervised the experiment and prepared the manuscript. NA conducted the work in the laboratory. $\mathrm{MH}$ performed the statistical analysis, participated in its design and submitted the manuscript. All authors read and approved the final manuscript.

\section{Acknowledgement}

The authors would like to acknowledge Mr. Badhan Saha, Scientific Officer in BCSIR (Bangladesh Council of Scientific and Industrial Research), Dhaka, Bangladesh for supporting As analysis.

\section{References}

1. Matschullat J. Arsenic in the geosphere-a review. Sci Total Environ. 2000;249:297-312. https://doi.org/10.1016/ S0048-9697(99)00524-0

2. Mandal BK, Suzuki KT. Arsenic around the world: a review. Talanta 2001;58:201-35. https://doi.org/10.1016/S0039-9140(02)00268-0

3. Kabata-Pendias A, Pendias H. Trace elements in soils and plants. Boca Raton, USA: CRC Press; 1992.

4. Islam MR, Meisner CA. Arsenic in paddy soils of Bangladesh: levels, distribution and contribution of irrigation and sediments. In: Behavior of arsenic in aquifers, soils and plants. Conference Proceedings, Dhaka; 2005.

5. Alam MB, Sattar MA. Assessment of arsenic contamination in soils and waters in some areas of Bangladesh. Water Sci Technol. 2000;42:185-93. https://doi.org/10.2166/wst.2000.0568

6. Meharg AA, Rahman MM. Arsenic contamination of Bangladesh paddy field soils: Implications for rice contribution to arsenic consumption. Environ Sci Technol. https://doi.org/10.1021/es0259842

2003;37:229-34

7. Imamul Huq SM, Joardar JC, Parvin S, Correll R, Naidu R. Arsenic contamination in food chain: arsenic transfer into food materials through groundwater irrigation. J Health Nutri. 2006;24(3):305-16.

8. British Geological Survey (BGS), Department of Public Health and Engineering (DPHE). Arsenic contamination of groundwater in Bangladesh. BGS technical report WC/ 00/19, British Geological Survey UK; 2001.

9. Ali MA. Fate of arsenic in the environment. In: Ahmed MF, editor. Arsenic contamination: Bangladesh perspective. ITN-Bangladesh, Dhaka; 2003.

10. Imamul Huq SM, Rahman A, Sultana N, Naidu R. Extent and severity of arsenic contamination in soils of Bangladesh. In: Ahmed MF, Ali MA, Adeel Z, editors. Fate of arsenic in the environment. BUET-UNU, Dhaka; 2003. 
11. Hall DO, Rao KK. Photosynthesis. 6th ed. Cambridge University Press, Cambridge, UK; 1996.

12. Sims DA, Gamon JA. Relationships between leaf pigment content and spectral reflectance across a wide range of species, leaf structure and developmental stages. Remote Sens Environ. 2002;81:337-54 https://doi.org/10.1016/S0034-4257(02)00010-X

13. Merzlyak MN, Gitelson AA, Chivkunova OB, Rakitin VY. Non-destructive optical detection of pigment changes during leaf senescence and fruit ripening. Physiol Plant. 1999;106:135-41. 3054.1999.106119.x https://doi.org/10.1034/j.1399-

14. Young AJ, Britton G. Carotenoids and oxidative stress. In: Baltscheffsky M, editor. Current Research in Photosynthesis. Dordrecht, Kluwer; 1990. https://doi.org/ 10.1007/978-94-009-0511-5 759

15. Smith E, Naidu R, Alston AM. Arsenic in the soil environment: A review. Adv Agron. 1998;64:149-95. https://doi.org/10.1016/S0065-2113(08)60504-0

16. Marin AR, Pezeshki SR, Masscheleyn PH, Choi HS. Effect of dimethylarsinic acid (DMAA) on growth, tissue arsenic and photosynthesis of rice plants. J Plant Nutr. 1993;16:865-80.

https://doi.org/10.1080/01904169309364580

17. Abedin MJ, Meharg AA. Relative toxicity of arsenite and arsenate on germination and early seedling growth of rice (Oryza sativa L.). Plant Soil. 2002;243(1):57-66. https://doi.org/10.1023/A:1019918100451

18. Abedin MJ, Cottep-Howells J, Meharg AA. Arsenic uptake and accumulation in rice (Oryza sativa L.) irrigated with contamination water. Plant Soil. 2002;240(2):311-19. https://doi.org/10.1023/A:1015792723288

19. Rahman MA, Rahman MM, Miah MAM, Khaled HM. Influence of soil arsenic concentrations in rice (Oryza sativa L.). J Subtrop Agric Res Dev. 2004;2:24-31.

20. Cox MS, Bell PF, Kovar JL. Different tolerance of canola to arsenic when grown hydroponically or in soil. J Plant Nutr. https://doi.org/10.1080/01904169609365224

21. Marin AR, Masscheleyn PH, Patrick WHJR. The influence of chemical form and concentration of arsenic on rice growth and tissue arsenic concentration. Plant Soil. 1992;139:175-83. https://doi.org/10.1007/BF00009308

22. USDA (United States Department of Agriculture). Soil survey manual. Soil survey staff, Bureau of plant industry, soils and agricultural engineering, Washington; 1951.

23. Fertilizer Recommendation Guide (FRG). Bangladesh Agricultural Research Council (BARC), Farmgate, Dhaka 1215; 2012. 247p.

24. Arnon DI. Copper enzymes in isolated chloroplast. Polyphenol oxidase in Beta vulgaris. J Plant Physiol. 1949;24(1):1-15. https://doi.org/10.1104/pp.24.1.1

25. Lichtenthaler $\mathrm{H}$, Wellburn A. Determination of total carotenoids and chl-a and $\mathrm{b}$ of leaf extracts in different solvents. Biochem Soc Trans. 1983;603:591-2. https://doi.org/10.1042/bst0110591

26. Imamul Huq SM, Alam MD, editors. A Handbook on analyses of soil, plant and water. BACER-DU, University of Dhaka, Bangladesh; 2005.

27. Gee GW, Bauder JW. Particle size analysis. In: Klute A, editor. Methods of soil analysis. Part-I (pp: 383-409). 2nd ed. Agron. Mongr. 9. ASA and SSSA, Madison,WI; 1986.

28. Jackson ML. Soil Chemical Analysis. Prentice Hall of India Pvt. Ltd., New Delhi; 1973.
29. USDA (United States Department of Agriculture). Soil survey laboratory manual, soil survey investigation report no. 42, version 4.0, USDA-NRCS, Nebraska, USA; 2004.

30. Murphy J, Riley JP. A modified single solution method for the determination of phosphate in natural water. Anal Chim Acta. 1962;27:31-36. https://doi.org/10.1016/S00032670(00)88444-5

31. Knudsen D, Petersen GA, Pratt PF. Lithium, sodium and potassium. In: Page AL, Miller RH, Roscoe Ellis Jr, editors. Methods of soil analysis Part-2, Chemical and microbial properties (pp. 225-247), ASA and SSSA, Madison,WI; 1982.

32. Blakemore LC, Searle PL, Darly BK. Extractable iron, aluminum and silicon. In: Blakemore L, editor. Methods for chemical analysis of soils (pp. 71-76), New Zealand Soil Bureau scientific report 10A, Lower Hutt: DISR; 1987.

33. Miteva E, Merakchiyska M. Response of chloroplasts and photosynthetic mechanism of bean plants to excess arsenic in soil. Bulg J Agric Sci. 2002;8:151-6.

34. Duel LE, Swoboda AR. Arsenic toxicity to cotton and soybeans. J Environ Qual. 1972;1(3):317-20. https://doi.org/10.2134/jeq1972.00472425000100030026x

35. Joardar JC, Rahman SM, Rahman A, Islam M, Imamul Huq SM, Kawai S. Effect of arsenic concentration in irrigation water and soil on the arsenic content of vegetables in Bangladesh. Int J Plant Soil Sci. 2014;3(1):85-98. https://doi.org/10.9734/IJPSS/2014/6652

36. Shaibur MR, Kawai S. Effect of arsenic on visible symptom and arsenic concentration in hydroponic Japanese mustard spinach. Environ Exp Bot. 2009;67:6570. https://doi.org/10.1016/j.envexpbot.2009.06.001

37. Mitchell P, Barr D. The nature and significance of public exposure to arsenic: a review of its relevance to south west England. Environ Geochem Health. 1995;17(2):5782. https://doi.org/10.1007/BF00146709

38. Hossain KM, Delowar I, Yoshida M, Harada AA, Sarkar MNH, Miah AHM, Uddin RMI, Adhana K, Perveen F. Growth and uptake of arsenic by rice irrigated with As contaminated water. J Food Agric Environ. 2005;3(2):287-91.

39. Stoeva N, Berova M, Zlatev Z. Physiological response of maize to arsenic contamination. Biol Plant. 2003;47(3):449-52.

https://doi.org/10.1023/B:BIOP.0000023893.12939.48

40. Wells B, Gilmor J. Sterility in rice cultivars as influenced by MSMA rate and water management. Agron J. 1997;69:451-54. https://doi.org/10.2134/agronj1977.00021962006900030029x

41. Stepakna V. The effect of arsenic on the yield and elemental composition of agricultural crops. Agrokhimiya. 1998;12:57-63.

42. Li JX, Cao H, Zhang FQ. Effects of $\mathrm{Cu}^{2+}$ and $\mathrm{Zn}^{2+}$ on growth of Triticum aestivum seedling. J Plant Resour Environ. 2005;14(4):59-60.

43. Rahman M, Hasegawa H, Mahfuzur M, Islam M. Effect of arsenic on photosynthesis, growth and yield of five widely cultivated rice (Oryza sativa L.) varieties in Bangladesh. Chemosphere. 2007;67:1072-9. https://doi.org/10.1016/j.chemosphere.2006.11.061

44. CAC (Codex Alimentarius Commission). Joint FAO/WHO food standards programme codex committee on contaminants in foods: discussion paper on arsenic in rice. The Hague, the Netherlands, 21-25 March, CX/CF 11/5/10; 2011 
45. CAC (Codex Alimentarius Commission). Joint FAO/WHO food standards programme CODEX alimentarius commission. 37th Session, Geneva, Switzerland, 14-18 July 2014. Report of the eighth session of the CODEX committee on contaminants in foods. The Hague, the Netherlands, 31 March-4 April, REP14/CF; 2014.

46. Zhao FJ, McGrath SP, Meharg AA. Arsenic as a food chain contaminant: mechanisms of plant uptake and metabolism and mitigation strategies. Annu Rev Plant Biol. 2010;61(1):535-59. https://doi.org/10.1146/annurevarplant-042809-112152

47. Schoof RA, Yost LJ, Eickhoff J, Crecelius EA, Cragin DW, Meacher DM, Menzel DB. A market basket survey of inorganic arsenic in food. Food Chem Toxicol.
1999;37(8):839-46. https://doi.org/10.1016/S0278-6915(99)00073-3

48. Roychowdhury $\mathrm{T}$, Tokunaga $\mathrm{H}$, Ando M. Survey of arsenic and other heavy metals in food composites and drinking water and estimation of dietary intake by the villagers from an arsenic-affected area of West Bengal, India. Sci Total Environ. 2003;308:15-35. https://doi.org/10.1016/S0048-9697(02)00612-5

49. Williams PN, Islam MR, Adomako EE, Raab A, Hossain SA, Zhu YG, Feldmann J, Meharg AA. Increase in rice grain arsenic for regions of Bangladesh irrigating paddies with elevated arsenic in groundwater. Environ Sci Technol. 2006;40(16):4903-8. 